\title{
Percentage Body Weight Gain
}

National Cancer Institute

\section{Source}

National Cancer Institute. Percentage Body Weight Gain. NCI Thesaurus. Code C90434.

The amount of weight gained over a period of time in relation to the total weight. 